\title{
Competitiveness of the Fishery Sector in Latvia
}

\author{
Inese Biukšāne \\ Institute of Agricultural Resources and Economics, Riga Technical University, Latvia
}

\begin{abstract}
The aim of the research is to evaluate the competitiveness of Fishery Sector in Latvia. Based on the author developed Model of the Factors influencing Competitiveness of the Fisheries Sector Cluster and methodology of the Index of Fishery Sector Competitiveness the authors determined the competitiveness level of Fishery Sector in Latvia and identified spheres influencing competitiveness: facilitating and promising spheres as well as procrastinatory and stagnating spheres, moreover the possibilities of further development were established. The author has developed the evaluation methodology of the Fishery Sector Competitiveness that can be used in any country in the Fishery Sector for the evaluation of competitiveness. The elaborated methodology for evaluation of competitiveness may assist the institutions involved in the Fisheries' policy formation to work more successfully and improve the common policy in the Fisheries sector.
\end{abstract}

Keywords: competitiveness, fishery, index, model.

\section{INTRODUCTION}

In the development of Latvia's economy fishery, which has been one of the most ancient people's activities, has always had a significant importance, especially in development of the coastal areas of the Baltic Sea and the Gulf of Riga. In Latvia, fishery has not only ancient history and traditions, but also an internal self-development potential. Using the support opportunities provided by the EU funding instruments and participating in formation of the Common Fisheries Policy, wide possibilities of facilitating competitiveness and growth reveal to the Latvian fishery sector.

The length of the Latvian border is $1836 \mathrm{~km}$ and the coastline is $494 \mathrm{~km} \log$ or $27 \%$, which is $0,7 \%$ of the total EU coastline of $66000 \mathrm{~km} \mathrm{[3].} \mathrm{The}$ territorial waters of the Baltic Sea, up to 12 sea miles from the coastline, also the economic area and continental shelf of the area of 28 thousand $\mathrm{km}^{2}$ are under the state jurisdiction [1].

Fishing opportunities and catch quotas in the Baltic Sea and the Gulf of Riga are available to Latvia, based on long-term environmental and fish resource study at the national and international level. According to the cross-border agreements concluded by Latvia, there are opportunities of fishing also in the economic areas of other countries and regions covered by the international conventions [6].

High-seas fisheries take place in the areas confirmed by the Northwest Atlantic Fisheries Organization (NAFO), Northeast Atlantic Fisheries Commission (NEAFC) and Fishery Committee for the Eastern Central Atlantic (NEAFC) [3].

In 2015, Latvian fishing fleet consisted of 686 fishing vessels with the total engine power of 43.30 thousand $\mathrm{kW}$ and total gross tonnage of 24.68 thousand (GT). The fishing fleet included 7 high-seas vessels, 68 ships, fishing in the Baltic Sea beyond the foreshore in the gulf, and coastal small volume fishing boats. The total catch in 2015 was 81.31 thousand tons. In the national territorial waters mostly the catch consisted of sprat, Baltic pilchard and cod, in turn, in high-seas - mostly scad, sardine, round sardinella and mackerel.

Environmental pollution, inimical spawning conditions as well as intensive fishing and other factors have negative impact on the fish stock, as a result the number of catch quotas and the amount of fish available in the Baltic Sea reduces, resulting in negative influence on the operation of fishery and fish processing companies, simultaneously increasing the role of the aquaculture sector in acquisition of alternative fish resources [6]

Several studies show that the Baltic Sea, which according to the World Wide Fund for Nature is one of the youngest seas and one of the largest bodies of brackish waters, is one of the most polluted seas in the world [13], not only due to the consequences of fishery activity, but also other factors (such as waste waters, rubbish, munition lying on the sea floor after World War II and chemicals it contains, etc.). The Baltic Sea is almost entirely closed; it is comparatively shallow (average depth $55 \mathrm{~km}$ ) and rarely freezes up. During severe winters mainly the Gulf of Riga, which is the shallowest of the big gulfs in the Baltic Sea (its average depth is $26 \mathrm{~m}$ ), freezes up and thus limits the fishing activities. Considering the unique ecosystem of the Baltic Sea determined by its special geographical and hydromorphological conditions [3] one must sustainably manage it.

ISSN 1691-5402

(C) Rezekne Academy of Technologies, Rezekne 2017 http://dx.doi.org/10.17770/etr2017vol1.2633 
The Common Fisheries Policy of the EU strives to ensure ecologically sustainable fisheries activities over a long term and fisheries management corresponding to the objective of ensuring benefits in economic, social and employment spheres, facilitating availability of food [4]. The overall objective of the Common Fisheries Policy is to ensure that fishing and aquaculture activities contribute to the creation of environmental conditions capable of being sustained long-term which are necessary for economic and social development. Moreover, it should foster increased productivity, a fair standard of living for the people employed in the fisheries sector and stable markets, and it should ensure the availability of resources and that products reach consumers at reasonable prices [5].

Facilitation of competitiveness has become one of the major objectives in the development strategy of companies, branches and countries [12]. Taking into account the dependence of fishery on the fishing opportunities, coordinated at the EU level corresponding to the principles of sustainability, and increase in global rivalry in the world markets, strengthening of fishery's competitiveness plays a significant role. Evaluation of competitiveness provides an opportunity to judge impartially and allows understanding the need in structural reforms and choice of priorities better.

Research aim - to evaluate the competitiveness of the fishery sector in Latvia. To reach the aim, the

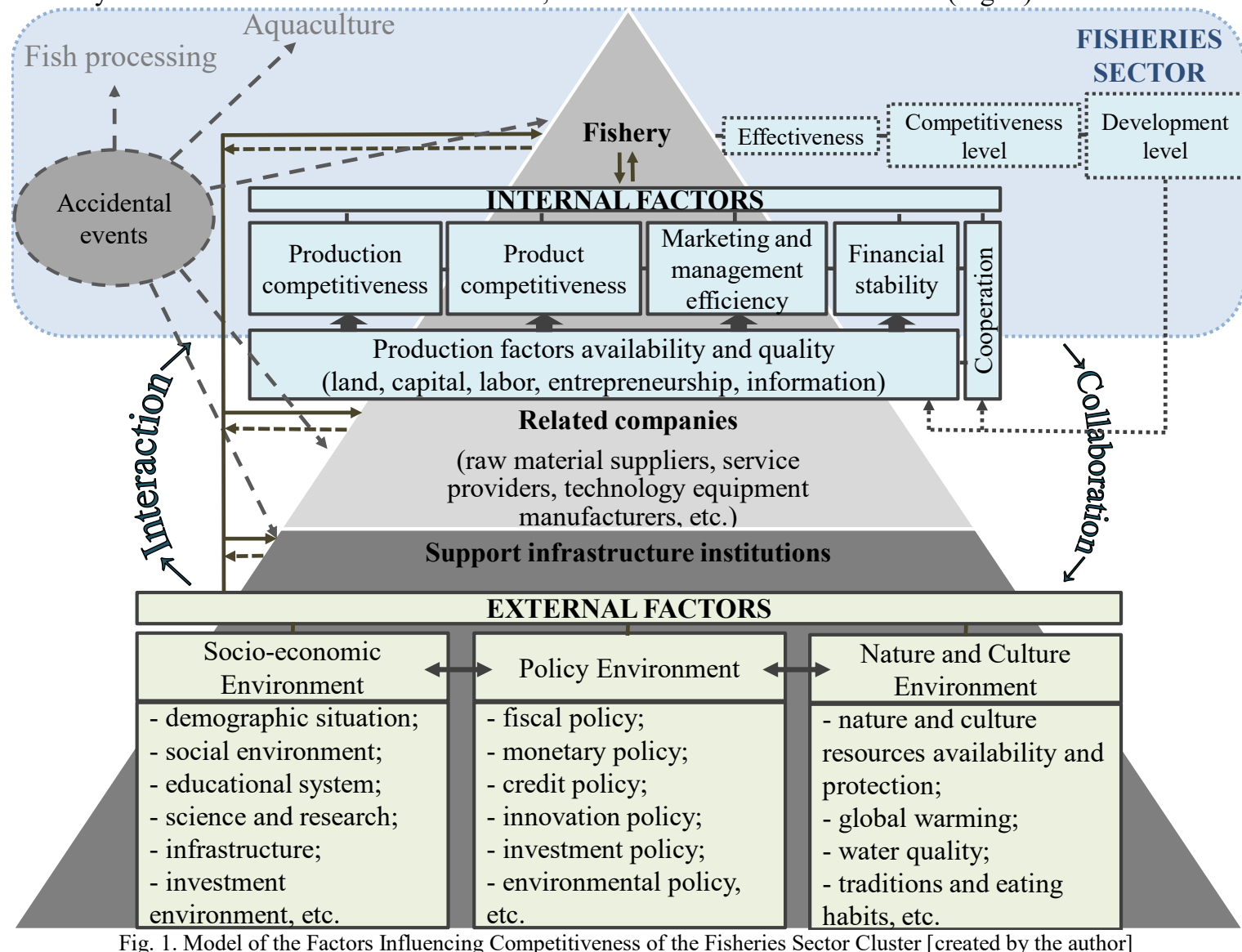

following work tasks were set: 1) to elaborate the methodology for competitiveness of the fishery sector; 2) to evaluate the competitiveness of the fishery sector in Latvia, identifying the spheres ensuring competitiveness.

The novelty of the research - developed evaluation methodology of the Fishery Sector Competitiveness that can be may assist the institutions involved in the fisheries' policy-making to work more successfully and improve the common policy in the fisheries sector.

The qualitative and quantitative research methods were used in the study, including the general scientific research methods, statistical research methods, mathematical methods and sociological research methods. Microsoft Excel was used in the processing and analysis of the study results.

\section{II.MATERIALS AND METHODS}

According to the Model of the Factors Influencing Competitiveness of the Fisheries Sector Cluster elaborated by the author one can identify factors influencing the competitiveness of the fisheries sector, and they are: various internal and external social, economic, political, natural and cultural environmental factors (including random events) and the ability to adapt them, as well as formation of mutual interaction and cooperation forms and relationship among affiliated companies and support infrastructure institutions (Fig. 1). 
To evaluate competitiveness of Latvia's fishery sector at the level of microeconomics, the author elaborated the Fishery Sector Competitiveness Index (Fig. 2).

The development of the Index is based on the Model of the Factors Influencing Competitiveness of the Fisheries Sector Cluster elaborated by the author.

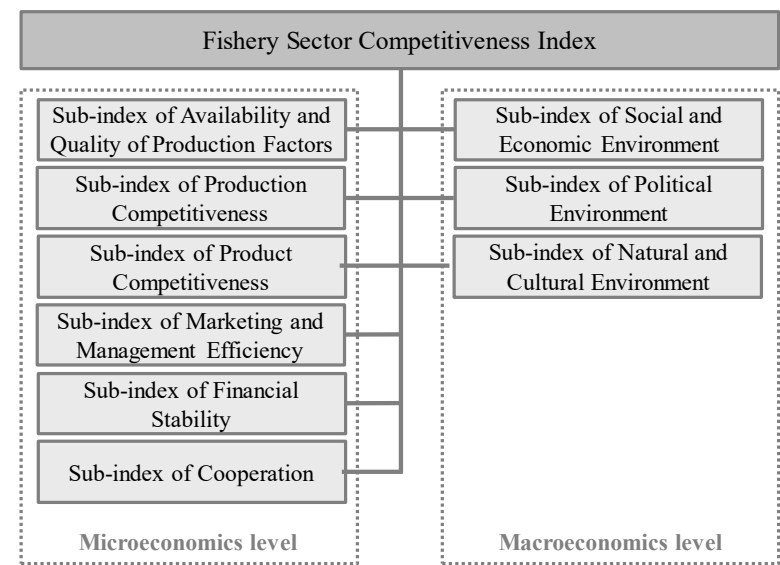

Fig. 2. Fishery Sector Competitiveness Index [created by the author]

Calculation of the Fishery Sector Competitiveness Index at the level of microeconomics is based on 6 sub-indexes in terms of functions from their relative proportions and normalized values of indicators of the factors influencing the competitiveness (1).

$$
S I=\alpha\left(I_{1}^{n v}+I_{2}^{n v}+I_{3}^{n v}+\ldots+I_{n}^{n v}\right)
$$

where: $S I$ - Sub-indexes, $\alpha$ - relative scales, $I_{1}^{n v} \ldots I_{n}^{n v}$ - indicators with the normalized values.

All in all, the author selected 22 indicators [7] and more than 35 sub-indicators as well as used several additional indicators, the choice of which was determined by the main conditions for indicators selection, elaborated by the author [9], to evaluate competitiveness. The author performed normalization of the indicators on the basis of min-max algorithm values from -5 to 5 .

The Index of the Fishery Sector Competitiveness is a tool for assessing the fishery competitiveness, which allows identified facilitating and promising spheres as well as procrastinatory and stagnating spheres influencing competitiveness.

The Index of the Fishery Sector Competitiveness can be used as a basis for the development of a specific strategy and the implementation of a proper investment policy (Table 1).

Table I

The promotion strategies of the competitiveness [created by the author]

\begin{tabular}{|c|c|c|c|c|}
\hline \multirow{2}{*}{ Competitiveness } & \multicolumn{5}{|c|}{ Strategy type } \\
\cline { 2 - 5 } & $\begin{array}{c}\text { Penetration } \\
\text { strategy }\end{array}$ & $\begin{array}{c}\text { Enlargement } \\
\text { strategy }\end{array}$ & $\begin{array}{c}\text { Development } \\
\text { strategy }\end{array}$ & $\begin{array}{c}\text { Improvement } \\
\text { strategy }\end{array}$ \\
\hline$C_{L(-0<)} ; G_{P(0 \leq)}$ & $\checkmark$ & - & - & - \\
\hline$C_{L(-0<)} ; G_{P(>0)}$ & - & $\checkmark$ & - & - \\
\hline$C_{L(>0)} ; G_{P(0 \leq)}$ & - & - & $\checkmark$ & - \\
\hline$C_{L(>0)} ; G_{P(>0)}$ & - & - & - & $\checkmark$ \\
\hline
\end{tabular}

where: $C_{L}$ - competitiveness level, $G_{P}$ - growth pace.

Penetration strategy foremostly provides for implementation of measures to strengthen spheres procrastinating competitiveness, where cooperation plays a significant role. Enlargement strategy foremostly provides for implementation of measures to strengthen spheres stagnating competitiveness. In turn, development strategy provides for implementation of measures to strengthen spheres promising competitiveness. Only improvement strategy provides for implementation of measures to strengthen spheres promising competitiveness.

The evaluation methodology of the Fishery Sector Competitiveness developed by the author can be used to evaluate competitiveness of the fishery sector of any country. The elaborated methodology for evaluation of competitiveness may assist the institutions involved in the Fisheries' policy formation to work more successfully and improve the common policy in the Fisheries sector.

\section{RESULTS AND DISCUSSION}

The competitiveness of the fishery sector in Latvia during the period from 2005 to 2014 is evaluated as medium-high (1.59) (Fig. 3).

In this period the competitiveness of the fishery sector in Latvia increased by $108 \%$ : from 1.00 in 2005 to 2.07 in 2014.

The fishery sector as any other sector of the economy has its own spheres that influence competitiveness - facilitating and procrastinatory spheres as well as promising and stagnating spheres, ensuring the competitiveness of the sector and its further development potential. 


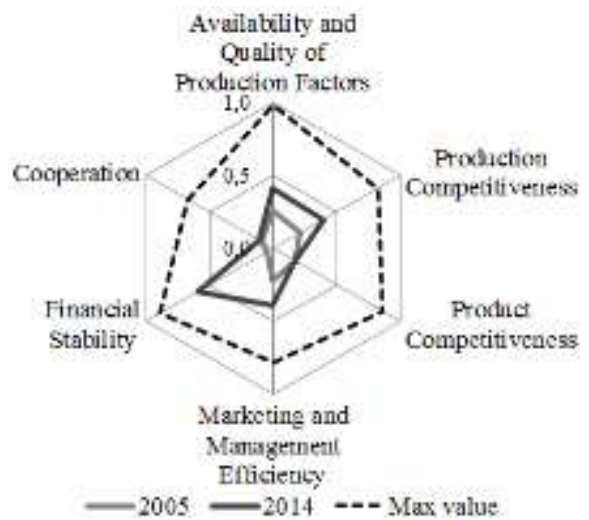

Fig. 3. The competitiveness assessment of Fishery Sector in Latvia according by the spheres in 2005 and 2014 (value of sub-indexes) [calculated and create by the author according to $2,10,11$ ]

The facilitating spheres of the fishery sector competitiveness are the financial stability, the marketing and management efficiency, the availability and quality of production factors, the production competitiveness as well as the cooperation. Although product competitiveness in the fishery sector may be evaluated as average high, currently it is in stagnation and a transitional stage between the facilitating and promising sphere (Fig. 4).

There was an average high level of competitiveness also in cooperation, in turn, high level of competitiveness - in availability and quality of production factors, production competitiveness, marketing and management efficiency as well as in financial stability. Fishery sector has no spheres procrastinatory and stagnating the competitiveness.

The companies that operate in the fishery sector in Latvia and the representatives of the institutions involved in the fisheries sector policy-making and implementation believe that the growth of the sector competitiveness can be promoted by the implementation of a number of interrelated and subordinated measures (Fig. 5).

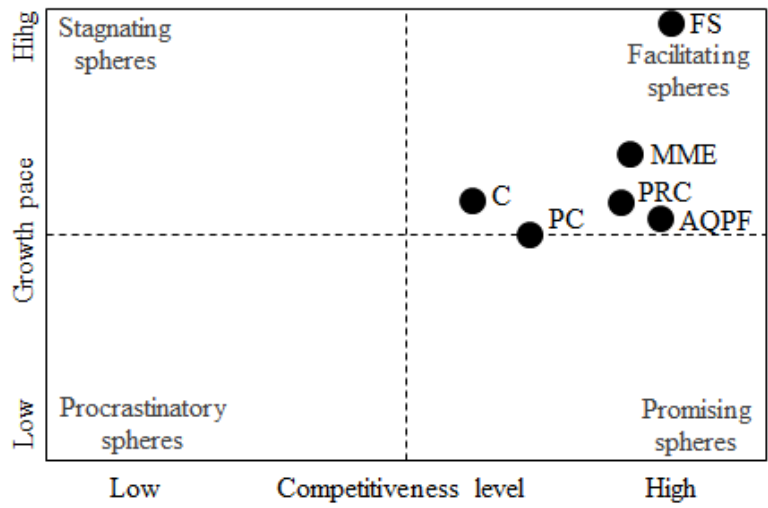

Fig. 4. The ensuring spheres of the competitiveness of Fishery Sector in Latvia [calculated and create by the author according to 2, $10,11]$

where: $A Q P F$ - Availability and Quality of Production Factors, $P R C$ - Production Competitiveness, $P C$ - Product Competitiveness, $M M E$ - Marketing and Management Efficiency, $F S$ - Financial Stability, $C$-Cooperation.

The competitiveness of the fishery sector in Latvia can be promoted by an efficient and rational use of EU financial instruments and support options provided by the state, making a cost optimization, as well as manufacturing innovative products of good quality with a high added value and creating a strong cooperation (particularly coastal fishery). According to the opinion of the companies and the representatives of the institutions involved in the fisheries sector policy-making and implementation the competitiveness of the fishery sector in Latvia can be also promoted by the other measures.

Collaboration with scientific institutions EU financial instruments and state support Learning and exchange experience Cooperation Export Marketing activities Products of high added value Innovative technologies Cost optimization Employee training and qualification

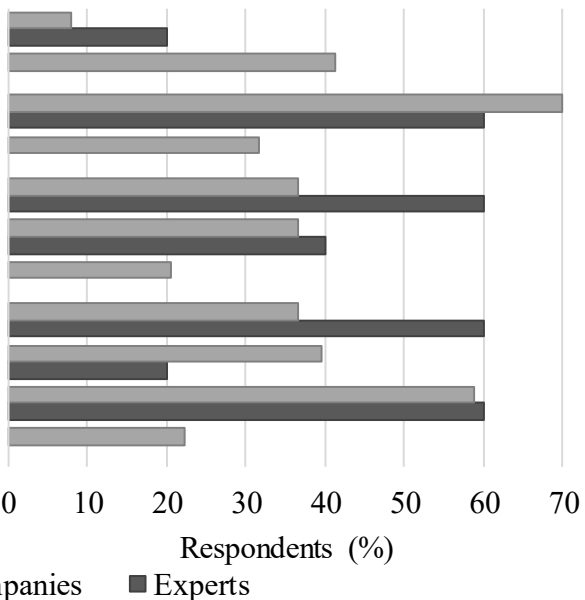

$\square$ Fishery companies Experts

Fig. 5. The promoting measures the competitiveness of Fishery Sector in Latvia (respondents, \%) [calculated and create by the author according to 8]

Although the measures proposed by the fishery companies and the representatives of the institutions involved in the fisheries sector policy-making and implementation are focused on promotion the competitiveness of the fishery sector in Latvia and they are considered useful, however, the author 
believes that the promoting measures should be structured and implemented according to the chosen development strategy and investment policy. There are several types of strategies, however, in the opinion of the author, to facilitate the competitiveness of the fishery sector in Latvia a strategy of corresponding approach should be developed.

For Latvia's fishery sector all the spheres are spheres facilitating competitiveness (except product competitiveness), consequently to contribute to the sector's competitiveness it is recommended to implement the improvement strategy. In the framework of development strategy one should foremostly implement measures to strengthen spheres facilitating competitiveness in the fishery sector, and only then - to strengthen the other its spheres.

\section{CONCLUSION}

In the development of the Latvia's economy fishery has always had a great importance. It has not only ancient history and traditions, but also an internal self-development potential, where using the support opportunities provided by the EU funding instruments and participating in formation of the Common Fisheries Policy of the EU wide opportunities of enhancing competitiveness open to the Latvia's fishery sector.

Currently the competitiveness of Latvia's fishery sector may be evaluated as average high, which is to a great extent ensured by financial stability, marketing and management efficiency, availability and quality of production factors, production competitiveness and cooperation. To facilitate the competitiveness of Latvia's fishery sector the author recommends implementing the improvement strategy.

\section{REFERENCES}

[1] Agriculture Ministry, "Ricibas programma zivsaimniecibas attistíbai 2014. - 2020. gadam (Operational Programme for Development of Fisheries 2014-2020)," CCI 2014LV14MFOP001, p. 138, 2014 (In Latvian).
[2] Central Statistical Bureau database, 2017. [Online]. Available: http://data.csb.gov.lv/pxweb/lv/?rxid=cdcb978c-22b0-416aaacc-aa650d3e2ce0 [Accesed: January 03, 2017] (restricted access data)

[3] European Commission, "Eiropas Jūrlietu un zivsaimniecības fonds Latvijā (European Maritime and Fisheries Fund in Latvia),” p. 4, 2014 (In Latvian).

[4] European Parliament and Council, "European Parliament and Council Regulation (EU) No. 1380/2013 on the Common Fisheries Policy, amending Council Regulations (EC) No 1954/2003 and (EC) No 1224/2009 and repealing Council Regulations (EC) No 2371/2002 and (EC) No 639/2004 and Council Decision 2004/585/EC," Official Journal of the EU, L 354, pp. 22-61, 28.12.2013.

[5] European Parliament and Council, "European Parliament and Council Regulation (EU) No. 508/2014 on the European Maritime and Fisheries Fund and repealing Council Regulations (EC) No 2328/2003, (EC) No 861/2006, (EC) No $1198 / 2006$ and (EC) No 791/2007 and Regulation (EU) No 1255/2011 of the European Parliament and of the Council," Official Journal of the EU, L 149, pp. 1-66, 20.05.2014.

[6] Finance Ministry, "Single Programming Document for Latvia. Objective 1 Programme 2004 - 2006," p. 365, 2003.

[7] I. Biukšāne, "Index of the Fisheries Sector Cluster Competitiveness: Internal factors," SGEM2016 Conference Proceedings, Book II, vol. 4, pp. 347-354, doi: 10.5593/SGEMSOCIAL2016/B24/S07.046, 2016.

[8] I. Biukšāne, "The results of the Interviews and the Questionnaire given by the representatives of the institutions involved in the Latvian fisheries sector policy-making and implementation and the fishery sector companies' survey results (18.03.2016. - 13.04.2016.)" (restricted access data).

[9] I. Biukšāne, I. Judrupa, "Evaluation of competitiveness of the fisheries sector cluster," International Scientific Conference "Research for Rural Development 2016" Proceedings, vol. 2, pp. 238-245, 2016.

[10] Latvian Fisheries integrated control and information system "LFICIS" database, 2017. [Online]. Available: https://zikis.zm.gov.lv/Account/LogOn [Accesed: January 03, 2017] (restricted access data).

[11] Producer organizations, "Latvian producer organizations data", 2017 (restricted access data)

[12] R. Škapars, E. Šumilo, Latvijas ekonomikas un sabiedrības pārstrukturizācijas ietekme uz uznēmējdarbības konkurētspēju un iedzìvotāju dzīves kvalitāti (Impact of Latvian Economy and Society Restructuring on the Competitiveness of Companies and life Quality of the Population). Rīga: LU Akadēmiskais apgāds, 2006, p. 339 (In Latvian).

[13] World Wide Fund for Nature, "Clean Baltic within Reach? How can a new chemical policy contribute to the protection of the Baltic Sea?,"p. 4, 2005. 